Noticiário 


\section{As cátedras do IEA}

\section{DARIO LUIS BORELLI}

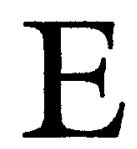

m outubro de 1991, dois meses depois de comemorar cinco anos de atividades ininterruptas, o Instituto de Estudos Avançados (IEA) da USP fez o pré-lançamento da Cátedra Jaime Cortesão com a palestra "Portugal como Objeto da (Sua) História Contemporânea", do professor Fernando Catroga, da Universidade de Coimbra.

Implantada no dia 8 de maio de 1991, a cátedra foi oficialmente inaugurada em abril deste ano pelos professores Luís Adão da Fonseca, da Universidade do Porto, e Jorge Couto, da Universidade de Coimbra. Eles realizaram palestras no IEA sobre o imaginário dos navegantes portugueses dos séculos 15 e 16 e a questáo da territorialidade na expansão portuguesa daquele período.

A Cátedra Jaime Cortesão resulta de um convênio entre a USP e a Comissão Nacional para as Comemoraçóes dos Descobrimentos Portugueses, presidida por Vasco Graça Moura, que esteve no País em companhia do primeiro-ministro Aníbal Cavaco e Silva. De acordo com o protocolo, válido até dezembro do ano 2000 , a cátedra promoverá iniciativas culturais e científicas centradas sobretudo no período dos descobrimentos. Neste posto circularão - a exemplo de congêneres internacionais - pesquisadores, escritores e artistas do mais alto padrão.

"A partir dessa cátedra um novo 'descobrimento' certamente virá a se produzir, nos mais variados campos do saber", disse o historiador Carlos Guilherme Mota, coordenador da cátedra no IEA. Acrescentou que a homenagem a Jaime Cortesáo é justa, uma vez que, além de historiador erudito, "foi brilhante geógrafo e homem de literatura, teorizando sobre os descobrimentos e o império português, discutindo temas cruciais como o bandeirismo e editando textos fundamentais como a carta de Caminha, os Diálogos sobre as Grandezas do Brasil e os Paulicea Monumenta Historica."

\section{Simón Bolívar}

Este ano, por um acordo entre a Fundação Memorial da América Latina (FMAL) e a USP, o IEA criou a Cátedra Simón Bolívar. $O$ do- 


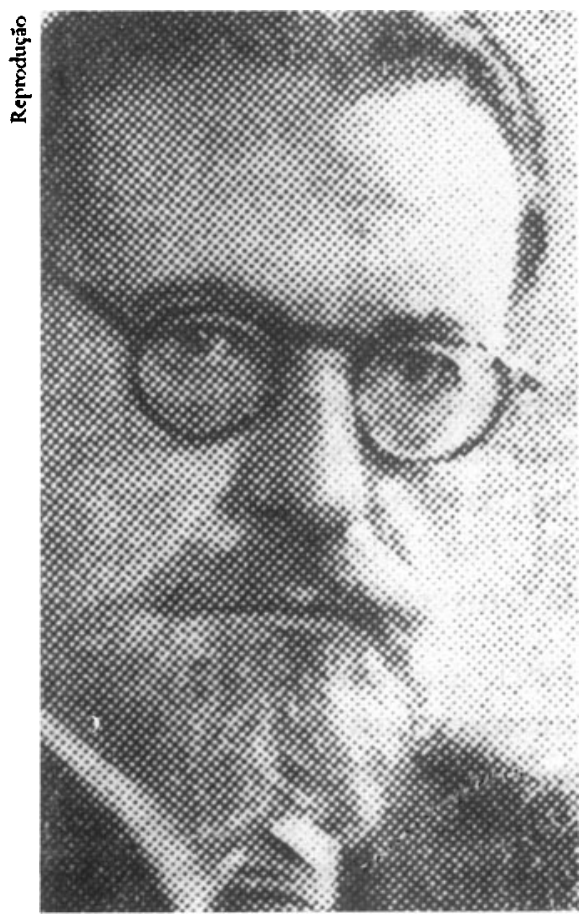

Jaime Corteš̃̃o, $1884-1960$

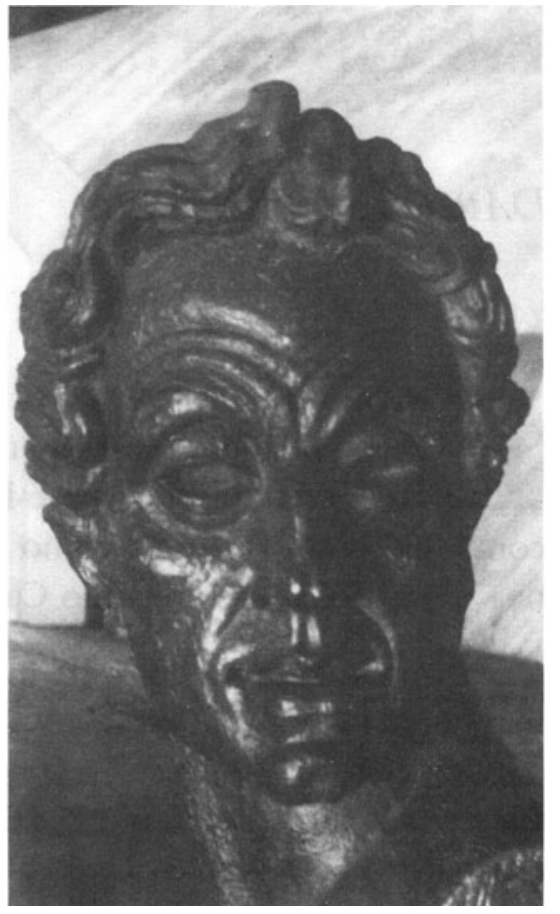

Simon Bolívar, $1783-1830$

cumento que a instituiu foi assinado no dia 20 de março de 1992 pelo reitor da USP, Roberto Leal Lobo e Silva Filho, e pelo presidente da FMAL, Paulo de Tarso Santos. Seu principal objetivo é desenvolver pesquisas sobre relações culturais, históricas e políticas dos países da América Latina e analisar seus problemas contemporâneos.

O lançamento da cátedra decorre do entendimento de que a integração econômica também depende de um número cada vez maior de estudos sobre as relaçóes culturais, históricas e políticas dos países da América Latina.

A Cátedra Simón Bolívar contará com pesquisadores escolhidos por uma Comissão de Orientação, composta por representantes da FMAL e do IEA. Os pesquisadores desenvolveráo atividades por um período de seis meses, renovável uma única vez por outros seis meses. A FMAL destinará uma verba anual em cruzeiros equivalente a US\$ 40 mil. O IEA terá a incumbência de manter a infra-estrutura necessária ao seu funcionamento.

Os pesquisadores escolhidos para a Cátedra Simón Bolívar deverão fazer um trabalho de pesquisa original, pronunciar conferências sobre a pesquisa em andamento e participar do programa de intercâmbio de jo- 
vens da FMAL. O primeiro titular da Cátedra Simón Bolívar será o sociólogo peruano Aníbal Quijano, autor dos livros Cultura y Dominacion (1980) e Modernidad, Identidad e Utopia en America Latina (1988), fundador do Centro de Investigaciones Sociales do Perú, professor da Universidade do Estado de Nova York e da Universidad de San Marcos e professor visitante do IEA (1991).

Dario Luis Borelli é assistente editorial da revista Entudos Apanfados. 